(C) 1989 ISIJ 論 文 二相ステンレス鋼の圧縮変形抵抗特性 "IIIIIIIIIIIIIIIIII

$$
\text { 品川一成*·石川孝司*2.細井・祐三*2 }
$$

\title{
Compressive Flow Stress-strain Behavior of Duplex Stainless Steels
}

Kazunari ShINAgawa, Takashi IsHIKAwa and Yuzo HosoI

\section{Synopsis :}

The compressive flow stress-strain behavior of duplex stainless steels composed of austenite and ferrite with various volume fractions is studied by static upsetting tests to the extent of large strain in the temperature range of cold working, from 30 to $350^{\circ} \mathrm{C}$. The flow stress of duplex stainless steels deformed to large strain at the temperature less than $200^{\circ} \mathrm{C}$ are higher than that estimated by the law of mixture. This difference is due to prior deformation of the softer austenite phase and its rapid work-hardenig in this temperature range. It is confirmed by a numerical analysis making use of rigid-plastic finite element method (FEM). As a result of present investigation, the flow stress model of duplex stainless steels is proposed and compared with the experimental data.

Key words : flow stress ; duplex stainless steel ; cold working ; numerical analysis.

\section{1. 緒 \\ 言}

冷間加てにおいて加工中の変形過程を解析するために 材料の特性を表す変形抵抗のデータが必要である。著者 らは前報1)において炭素鋼およびステンレス鋼の圧縮変 形抵抗特性を調べ，それぞれの特徵を明らかにした。そ して解析にそのまま利用できるようそれぞれの変形抵抗 を歪み, 歪み速度, 温度の関数として定式化した，延性 二相合金の変形挙動については多くの研究 2 (2) がなさ れているが二相ステンレス鋼についてのものは少なく, また，主に引張試験によるものであり，冷間鍛造時のよ うな压縮で, 高歪み域までの変形抵抗の研究はほとんど ない、また, 実際の生産現場では, 生産性を向上させる ために加工速度を高める傾向にあるので，変形抵抗は歪 み速度による影響とともに，素材内部での熱の蓄積によ る温度上昇のための軟化が起こることになる. 従ってこ
のような条件下での変形抵抗を考える場合は温度の影響 も考慮する必要がある.

本研究ではこのようなことから, オーステナイト相, フェライト相の比率を変えた二相ステンレス鋼とその基 礎となるオーステナイトステンレス鋼, フェライトステ ンレス鋼について冷間の範囲で温度を変えて圧縮試験を 行い, 変形抵抗を測定した。また，剛塑性有限要素法を 用いた二相材のモデル解析を行い, 実験結果について考 察を加えた。この考察によって二相ステンレス鋼の変形 抵抗を構成相の変形抵抗で表示する式を提案し, 実験結 果の説明を試みた。

\section{2. 実 験 方 法}

\section{$2 \cdot 1$ 供試材}

供試材の成分を Table 1 に示す。これらは田村らの 研究 $^{3)}$ を参考に，フェライト相中の濃度が $\mathrm{Cr} 35 \%, \mathrm{Ni}$

Table 1. Chemical compositions (wt \%) and volume fraction of austenite (V.F.A.).

\begin{tabular}{c|cccccrrr}
\hline Steels & C & Si & Mn & P & S & Ni & Cr \\
\hline F & 0.004 & 0.01 & 0.01 & 0.001 & 0.001 & 5.18 & 35.35 \\
D1 & 0.003 & 0.01 & 0.01 & 0.001 & 0.001 & 6.23 & 33.35 \\
D2 & 0.003 & 0.04 & 0.001 & 0.001 & 0.001 & 7.94 & 31.91 \\
D3 & 0.003 & 0.04 & 0.01 & 0.002 & 0.001 & 10.9 & 25.9 & 28.86 \\
D4 & 0.003 & 0.02 & 0.01 & 0.001 & 0.0005 & 14.11 & 26.00 \\
D5 & 0.002 & 0.01 & 0.01 & 0.001 & 0.0003 & 15.59 & 24.34 & 81.8 \\
A & 0.003 & 0.03 & 0.016 & 0.001 & 0.001 & 16.96 & 23.15 \\
\hline
\end{tabular}

昭和 63 年 4 月本会講演大会にて発表 平成元年 1 月 9 日受付 (Received Jan. 9, 1989)

* 名古屋大学大学院 (現: 大阪大学基礎工学部) (Graduate School, Nagoya University, Now Faculty of Engineering Science, Osaka University, 1-1 Machikaneyama-cho Toyonaka 560)

*2 名古屋大学工学部 I博 (Faculty of Engineering, Nagoya University) 


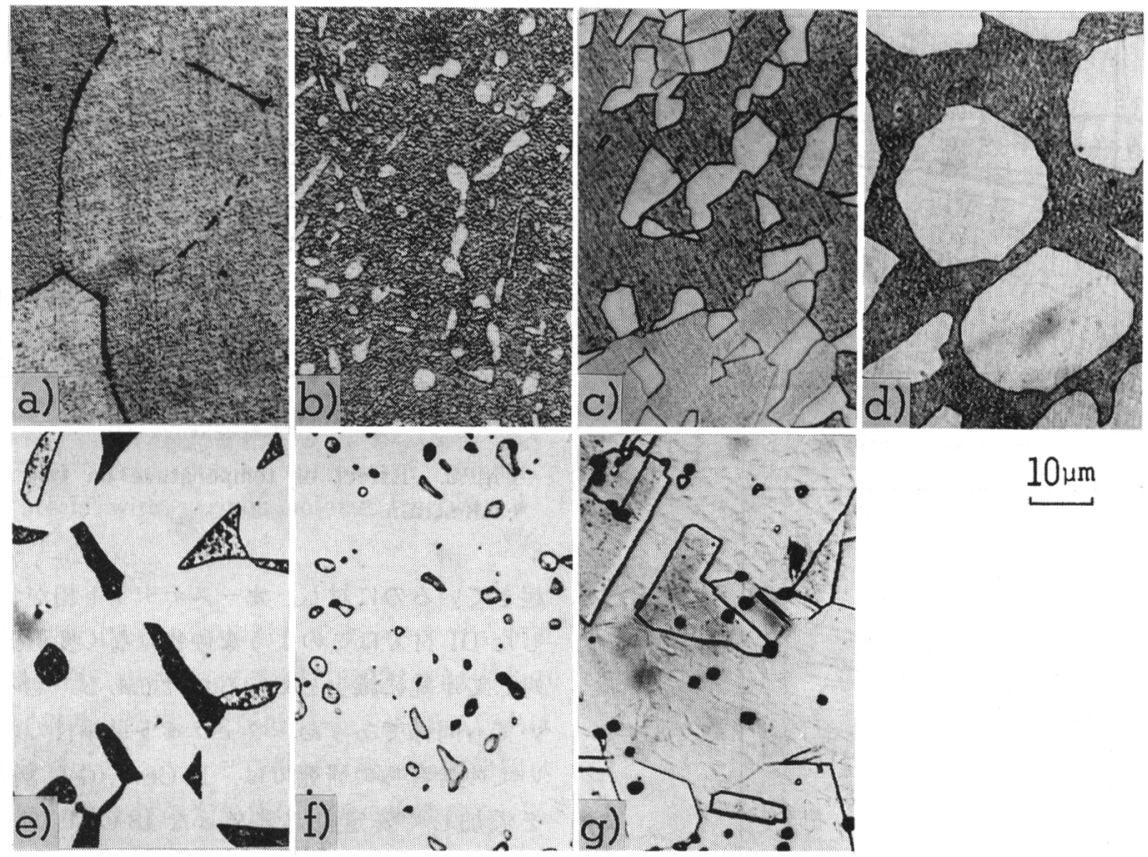

Photo. 1. Optical micrographs of duplex stainless steels composed of austenite and ferrite : a) F, b) D1, c) D2, d) D3, e) D4, f) D5, g) A.

$5 \%$ ，オーステナイト相中の濃度が Cr 23\%, Ni 17\% で 一定で，混合の割合のみが異なるようにした。それぞれ の試料は熱間般造で棒状に加工した後，900〜 $1200^{\circ} \mathrm{C}$ での各熱処理によってなるべく同程度の結晶粒径(10〜

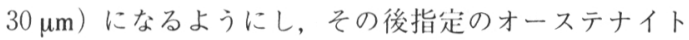
相，フェライト相比になるように調整した。 ただし，フェ ライト鋼については他鋼よりも結晶粒は大きくなった $(100 \mu \mathrm{m}$ 程度). 各相の $\mathrm{Cr} \%, \mathrm{Ni} \%$ はPMA 分析で ほほ等しいことを確認した。組織写真を Photo. 1 に示 す。 D1，D2，D3 材はフェライト母相中にオーステナ イト相が孤立的に，D4，D5 材はオーステナイト母相中 にフェライト相が孤立的に析出している.

\section{$2 \cdot 2$ 実験方法}

据込み試験は油压式压縮試験機を用いて前報と同様, 端面拘束圧縮法 ${ }^{9)}$ に基ついて行った。据込み速度は変形 熱による温度上昇が起こらないよう, 目安を 0.5 $\mathrm{mm} / \mathrm{min}$ (歪み速度 $\dot{\bar{\varepsilon}}=10^{-3} \mathrm{~s}^{-1}$ 程度) に扔いた。試

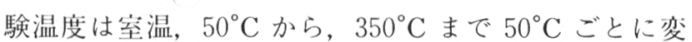
えた．試片の加熱は，压板の間にはさんで压板ごとヒー ターで加熱した。 その際試片側面に熱電対を付け, それ により試験温度を調節して試験を行った。

\section{3. 実験結果及び考察}

\section{$3 \cdot 1$ 二相ステンレス鋼の変形抵抗特性}

Fig. 1 にフェライト単相の F材，オーステナイト単相 の $\mathrm{A}$ 材および二相鋼の代表としてオーステナイト体積率 $50 \%$ D 3 材の変形抵抗-歪み曲線を示す。F 材では $300^{\circ} \mathrm{C}$ で加工硬化が大きくなっているが，この異常を除 いて考えると, フェライト鋼の変形抵抗の特徴としては 変形抵抗一歪み曲線の形は, 温度の影響を受けずにその 高さだけが咸少していくだけで変わらないということで ある。一方オーステナイト鋼では降伏応力けは温度に よってほとんど変化しない. 加工硬化は温度の影響を強 く受け，室温で加工硬化が大きいのに対し，温度が上昇 すると急激に小さくなる。 D3 材では室温でフェライト 鋼に比べ加工硬化が大きいが，オーステナイト鋼同様に 温度が上昇するとともに小さくなる，また，降伏応力は オーステナイト鋼に比べ温度による軟化が大きい。この ように二相ステンレス鋼は両鋼の特徴を持っているとい える。

†本尖験では歪み $0.2 \%$ の精度はないので, 応力一歪み曲線において直 線から離れ始める点を降伏応力とした。 

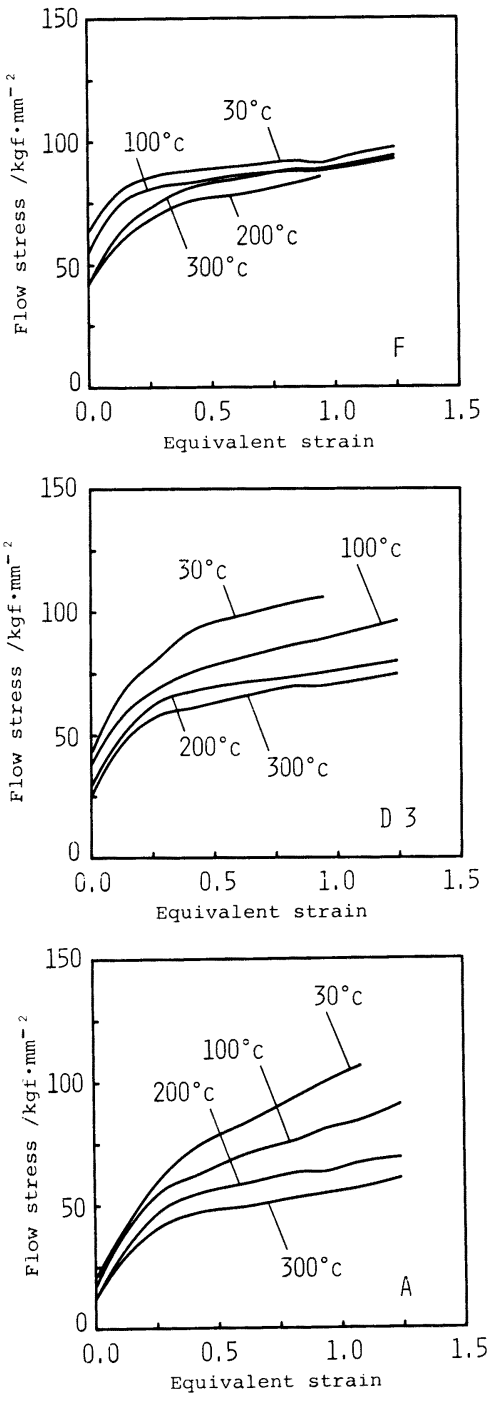

Fig. 1. Flow stress-strain curves at various temperature.

\section{$3 \cdot 2$ 二相材の変形抵抗}

ここでは二相ステンレス鋼をフェライト相とオーステ ナイト相からなる二相材としてとらえ考祭をする.

$3 \cdot 2 \cdot 1$ 二相材のフェライト相及びオーステナイト相 の変形抵抗

本研究ではフェライト単相材と二相材中のフェライト 相の $\mathrm{Cr}, \mathrm{Ni} \%$ を同程度になるようにしたので, 両者の 変形抵抗特性はほほ同じになると考えられたが異なるこ とを示す結果が得られた。 Fig. 2 はF材，D1 材につい て各歪みでの変形抵抗を, 横軸を温度にとって示したも のである.フェライト単相材では, $200^{\circ} \mathrm{C}$ 以上で硬化が

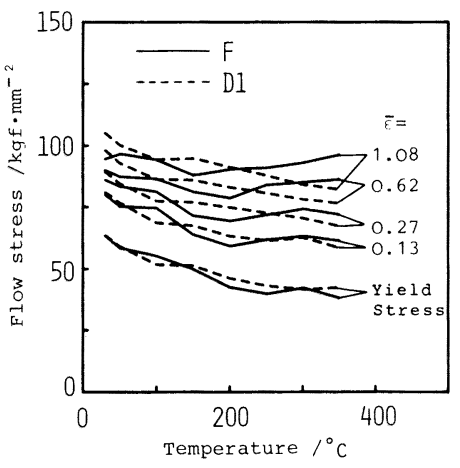

Fig. 2. Effect of temperature on flow stress at each strain.

起きているのに対し，オーステナイト相がわずかに析出 したD1 材ではこのような硬化はなく変形抵抗は温度に 対して単純に減少しているだけである．他の二相材につ いても同様であったフフェイト単相材のこの硬化につ いての著者らの研究では, $18 \mathrm{Cr}-0.04 \mathrm{C}$ 鋼とこれに $\mathrm{Nb}$ を添加して安定化処理をした $18 \mathrm{Cr}-0.04 \mathrm{C}-0.5 \mathrm{Nb}$ 鋼 について同様な試験をしたところ，18 Cr-0.04 C 鋼は $200^{\circ} \mathrm{C}$ 以上で硬化が起きたが安定化した鋼では D1 材と 同様 $200^{\circ} \mathrm{C}$ 以上での硬化はみられなかった。したがっ てこの硬化はフェライト中の自由な炭素のためと考えら れる.これは本実験の F 材でもそうであるが, 炭素量が 数 $10 \mathrm{ppm}$ のオーダーでも起きている.この詳細につい ては続報として報告する予定である。二相材でこれがな くなるのはオーステナイト相中に炭素が濃化し，フェラ イト相中の濃度が低下したためと考えられる．従ってこ の場合, 二相材中のフェライト相の変形抵抗は, オース テナイト相がわずかにフェライト壮相に析出しただけの D1 材に似ていると考えられる.

このほかにフェライト単相材が他の鋼に比べ結晶粒が 大きいということもあり, 二相材中のフェライト相の変 形抵抗は，D1 材を参考にすることにする．なお，オー ステナイト相は A 材と同じ挙動をすると考える.

$3 \cdot 2 \cdot 2$ 変形抵抗曲線へのフェライト, オーステナイ ト相比の影響

Fig. 3 に D1〜D5, $\mathrm{A}$ 材の $30^{\circ} \mathrm{C}$ および $200^{\circ} \mathrm{C}$ での変 形抵抗曲線を示す。オーステナイト相の变形抵抗曲線を $\mathrm{A}$ 材の変形抵抗曲線, フェライト相の変形抵抗曲線を D1 材の変形抵抗曲線と考えるとオーステナイト相の降 伏忍力はフェライト相のものに此べると小さい.しかし， $30^{\circ} \mathrm{C}$ ではオーステナイト相は加1.硬化が大きいので歪 みが 0.9 くらいで両相の変形抵抗は等しくなり, その 後は逆転している。一方，温度が上昇するとフェライト 


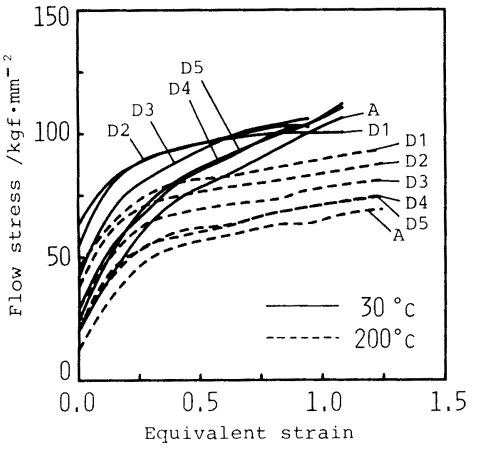

Fig. 3. Flow stress-strain curves of duplex stainless steels with various volume fraction of austenite.

相の加、硬化は変化しないのに对してオーステナイト相 の加厂硬化は急激に小さくなるため， $200^{\circ} \mathrm{C}$ では両者の 加上硬化は京程度となり，変形抵抗一歪み曲線の形がほ ほ同じとなっている。ここで一相材の変形抵抗曲線は $30^{\circ} \mathrm{C}$ では $\mathrm{D} 1$ 材と $\mathrm{A}$ 材の変形抵抗曲線の中間になく, 加-が進むと D1 材の変形抵抗曲線を超えて上に位置す

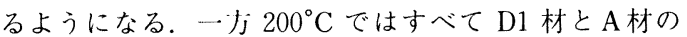
中間に位㯰し、その形はすべて D1，A 材とほぼ间じと なっている。

横軸をオーステナイト体積率にとって各歪みでの変形 抵抗をみると Fig. 4 のようになる。いま，フェライト 単相材の変形抵抗を $\bar{\sigma}_{l}$, オーステナイト単相材の変形 抵抗を $\bar{\sigma}_{A}$ とすると二相材の変形抵抗 $\bar{\sigma}_{D}$ は一般に

$$
\bar{\sigma}_{D}=\bar{\sigma}_{F} \cdot V_{F}+\bar{\sigma}_{A} \cdot V_{A}
$$

と表せる ${ }^{4)}$ 。ここに， $V_{F}$ : フェライト相の体積率， $V_{A}$ ： オーステナイト相の体積譬, $V_{F}+V_{A}=1$

この式(1) が成り立てば $\bar{\sigma}_{D}$ と $V_{F}$ あるいは $V_{A}$ とは 直線関係，すなわち混命則を示すことになる。この混命 則は二相材中の而相が均等に変形するときに成り立つと 考えられる.さて，Fig. 4 に示した $30^{\circ} \mathrm{C} て ゙ の$ 結果は二 相中の変形抵抗 $\bar{\sigma}_{D}$ と $V_{A}$ との間には直線関係は成り立 たず，混命則で得られる值より大きくなっている，その ずれはオーステナイト体積率 $50 \%$ あたりで最大となっ ている。これはフェライト相とオーステナイト相の変形 抵抗に差があるので耐相の間で不均一な変形をしたため

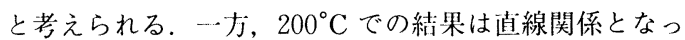
て抒り，混合則が成り立っている。これは両相が均等に 変形しているようにも見受けられるが， $200^{\circ} \mathrm{C}$ 以上でも 両相の変形抵抗には差があるので均等に変形するとは考 えにくい. $30^{\circ} \mathrm{C}$ での混命則からのずれは，温度が上昇 し $200^{\circ} \mathrm{C}$ になってオーステナイト相の加I硬化がフ工
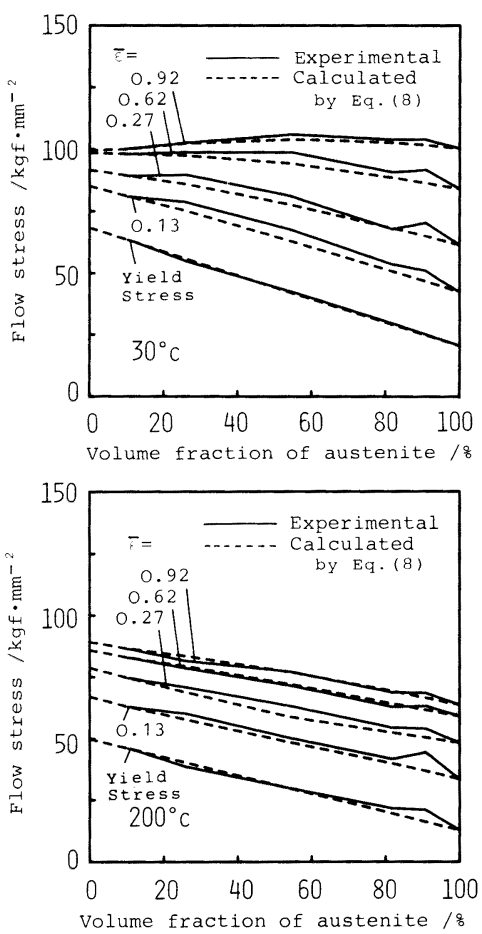

Fig. 4. Effect of volume fraction of austenite on flow stress at each strain.

ライト相と同じになったところでなくなる，実験は $350^{\circ} \mathrm{C}$ まで行っているが, $200^{\circ} \mathrm{C}$ 以上ではすべて同様な 結果が得られている. $200^{\circ} \mathrm{C}$ 以下と $200^{\circ} \mathrm{C}$ 以上で唯一 異なるのはオーステナイトの加洒硬化の大きさと考えら れる。 そこで，大変形をした場命の両相の変形の挙動と 変形抵抗に及ぼすオーステナイト相の加-硬化の影響を 明らかにするため, 剛塑性有限要素法によるモデル二相 材料の変形挙動を解析し検討を加えることにする.

\section{4. 剛塑性有限要素法による検討}

\section{$4 \cdot 1$ モデル}

解析には森らの開発した压縮性材料の塑性力学に基づ いた剛塑性有限要素法10)を用いた。これは弾性域を無 視し，両相ともはじめから塑性変形をすると仮定してあ るため, 降伏点付近の解析はできないが, 高歪み域まで の変形解析に有効である. 計算は本来 3 次元のモデルを 使って行うべきであるが，計算コス卜等を考え，2次元 の平面歪み問題として解析した。

解析に利用したモデルを Fig. 5 に示す. Photo. 1 に 示されるように，析出相は不規則に析出しているが，そ のような状態をモデル化するのは要素数が莫大になり， 
それを用いて大変形まで解析するのは計算コスト等の問 題で現実的でないと考え，Fig. 5（a）に示すように第 二相は規則正しく並んでいると仮定した。これらの対称 性から网に示した斜線部だけを解析した。Fig. 5 (b) に示すように压縮方问は $Z$ 軸とし, 側面上の節点の $X$ 軸方们速度はすべて等しくなるように速度の境界条件を 設定した。

Fig. 6 に要素分割を示す。要素は縦 $10 \times$ 横 20 とし た。オーステナイト体積率は，10，25，50，75，90\% の 5 種類とし, Photo. 1 を参考にオーステナイト体積 率 10，25，50\%までは，フェライト相中にオーステナ イト相が析出，オーステナイト体積率 75 ，90\%はオー ステナイト相中にフェライト相が析出しているとした。

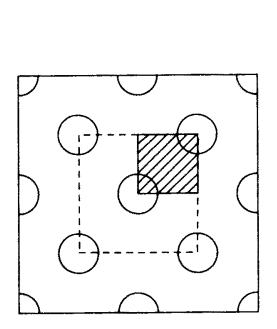

(a)

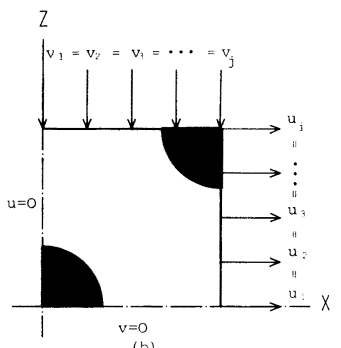

\footnotetext{
(a) Zone of calculation

(b) Velocity boundary condition
}

Fig. 5. Model of FEM analysis for duplex stainless steels.
そして, 各相別做の変形抵抗特性を与えることにより， 二相鋼の変形挙動を解析した。

\section{$4 \cdot 2$ 变形抵抗式}

両相の変形抵抗式は先の研究維果より ${ }^{1}$ 次式を用い た.

$$
\text { フェライト相: }
$$$$
\vec{\sigma}_{F}=A+B \cdot \varepsilon^{-n}
$$

$30^{\circ} \mathrm{C}$ のとき $A=15.6, \quad B=31.6, \quad n=0.100$

$200^{\circ} \mathrm{C}$ のとき $A=26.5, B=31.6, \quad n=0.306$

オーステナイト相 :

$$
\begin{aligned}
& \bar{\sigma}_{A}=A \cdot \bar{\varepsilon}+B \quad \bar{\varepsilon}<\bar{\varepsilon}_{1} \\
& \bar{\sigma}_{A}=A \cdot \bar{\varepsilon}_{1}+B \cdot\left[\begin{array}{c}
\bar{\varepsilon}-\bar{\varepsilon}_{0} \\
\hdashline \bar{\varepsilon}_{1}-\overline{\varepsilon_{0}}
\end{array}\right]^{n} \quad \bar{\varepsilon} \geqq \bar{\varepsilon}_{1} \\
& 30^{\circ} \mathrm{C} \text { のとき } A=159.0, \quad B=20.3, \quad n=0.475 \text {, } \\
& \varepsilon_{1}=0.196 \\
& 200^{\circ} \mathrm{C} \text { のとき } A=159.0, B=13.6, \quad n=0.332 \text {, } \\
& \varepsilon_{1}=0.144
\end{aligned}
$$

\section{$4 \cdot 3$ 解析結果}

$4 \cdot 3 \cdot 1$ 変形状態

Fig. 7 に $30^{\circ} \mathrm{C}$ で压絔方们柾み $\varepsilon_{Z}=0.36$ における オーステナイト体積率 $10 \%$ と $90 \%$ の変形状態を示す.

Fig. 7（a）に示したオーステナイト体積浢 10\%の場合 は，硬いフェライト相中に軟らかいオーステナイトがあ るため,オーステナイト相が比較的よく変形している.

Fig. 7（b）に示したオーステナイト体積淬 $90 \%$ の場合
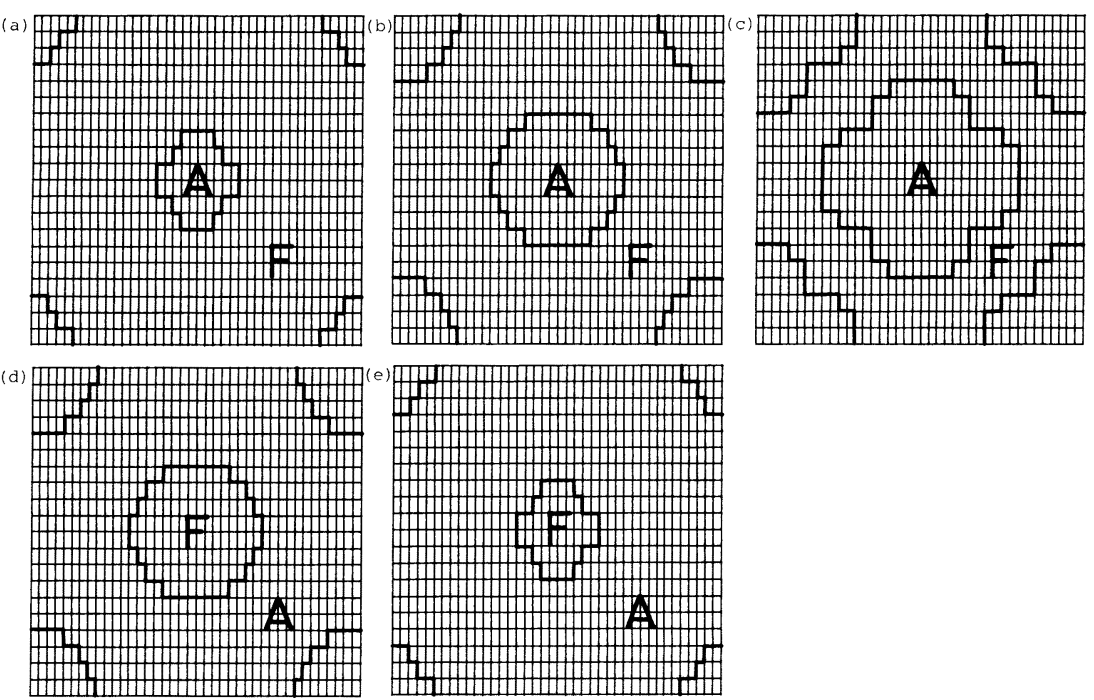

Fig. 6. Mesh in FEM calculation for duplex stainless steel models with various volume fraction of austenite : (a) $10 \%$, (b) $25 \%$, (c) $50 \%$, (d) $75 \%$, (e) $90 \%$, A : Austenite phase, F : Ferrite phase. 

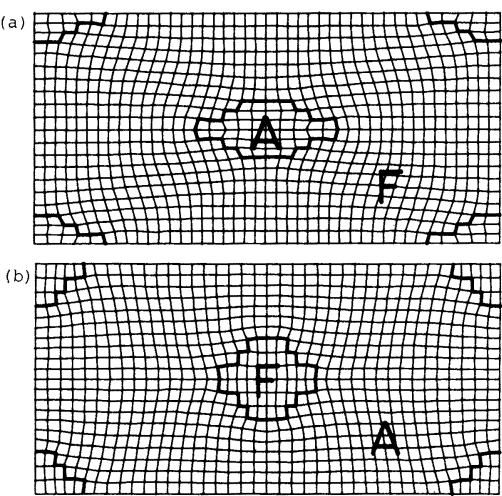

Fig. 7. Distorted grid pattern at $\varepsilon_{Z}=0.36$ in duplex stainless steel model: volume fraction of austenite (a) $10 \%$, (b) $90 \%$.

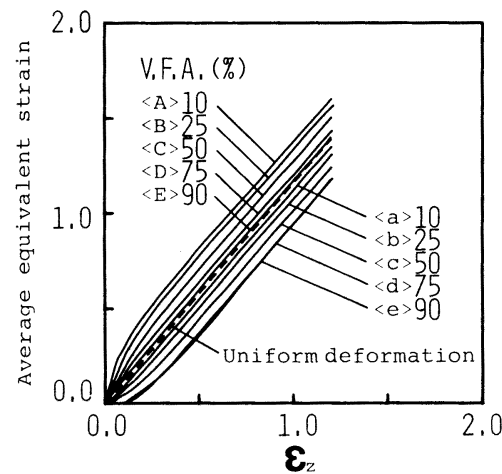

Fig. 8. Average equivalent strain of austenite phase (capital letters) and ferrite phase (small letters) calculated by FEM in duplex stainless steel models with various volume fraction of austenite (V.F.A.).

は軟らかいオーステナイト中に硬いフェライト相がある ため, フェライト相はオーステナイト体積率 $10 \%$ のと きに比べ変形の度命いが少ない。

Fig. 8 に両相の相当歪みの平均值の推移を示す. オー ステナイト相の体積が小さいほどオーステナイト相の歪 みの集中が大きくなっている，逆にフェライト相の体積 が小さいほどフェライト相の変形は小さくなっており, オーステナイト体積浢 $75 \%$ ，90\%の場合はフェライト 相が孤立。しているためフェライト相は加工開始時にはほ とんど変形していない.

ここで両相の塑性変形の度合いをみるため, 両相それ ぞれの相当歪み増分の平均值の比

$m=d \bar{\varepsilon}_{F} / d \bar{\varepsilon}_{A}$

をとり，压縮方向の歪みについてプロットしたのが
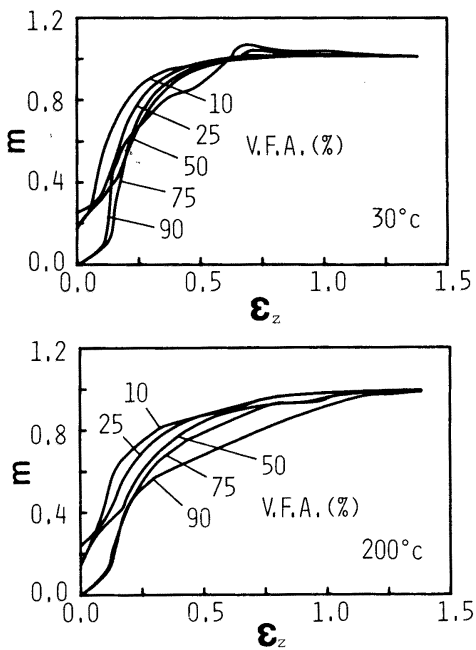

Fig. 9. Calculated ratio $\mathrm{m}$ of incremental average equivalent strain of austenite phase to that of ferrite phase in duplex stainless steel models with volume fraction of austenite $(V . F . A$.) as a function of $\varepsilon_{Z}$.

Fig. 9 である. $m=0$ のときは $d \bar{\varepsilon}_{F}=0$ となり, オース テナイト相のみが塑性変形, $m=1$ のときには $d \bar{\varepsilon}_{F}=$ $d \bar{\varepsilon}_{A}$ となり両相が均等に変形していることを表す.

$30^{\circ} \mathrm{C}$ では変形が進むと, オーステナイト相が加工硬 化し, その変形抵抗がフェライト相のそれと同程度にな るときに，両相の平均歪み増分が等しく $(m=1)$ なる と考えられる。また，さらに変形が進むとオーステナイ ト相の変形抵抗はフェライト相の変形抵抗より大きくな るが,これによって逆にフェライト相の平均歪み増分が オーステナイト相のそれより大きくなるということはな く, $m$ は1に収束する。これは, 加1が進行すると, 両相ともつぶれて，第一相は Fig. 7 のように横に長く 伸びるためと考えられる。こうなると耐相どうしの距離 が短くなり，拘束が強くなる，すなわち，はじめは両相 が自由な変形ができる状態であっても, 加ににより両相 の形態が変化することによって拘束が強くなって変形が 均等に進行すると考えられる.

同様な理由で $200^{\circ} \mathrm{C}$ では，オーステナイト相は加】. 硬化が小さく, 変形抵抗はフェライト相より小さいまま であるが， $30^{\circ} \mathrm{C}$ に比べ遅いものの $m$ は 1 に収束する.

$4 \cdot 3 \cdot 2$ 平均相当心力-平均相当歪みの関係

FEM 計算における各要素の相当忍力, 相当歪みの全 体での平均と, 構成相ごとの平均との関係は次式のよう になる。

$\bar{\sigma}_{D, \text { ave. }}=\bar{\sigma}_{F, \text { ave. }} \cdot V_{F}+\bar{\sigma}_{A, \text { ave. }} \cdot V_{A}$ 

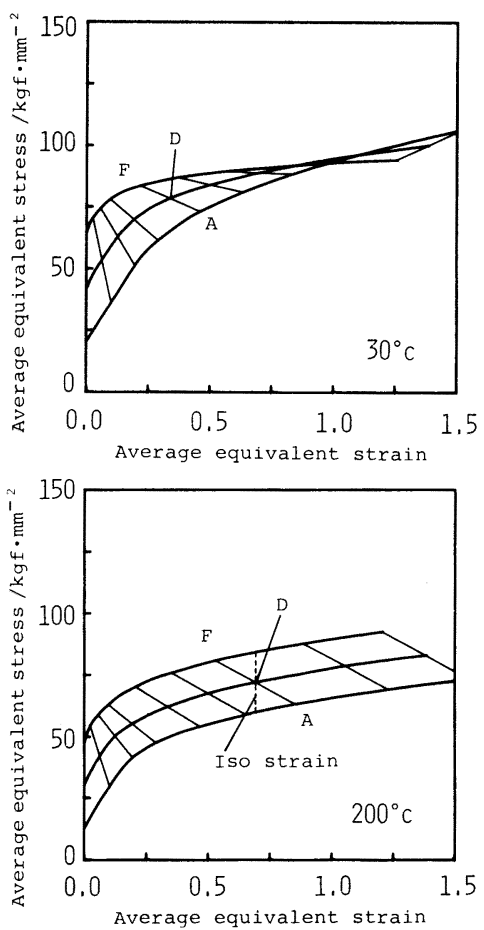

Fig. 10. Average equivalent stress-average equivalent strain curves in duplex stainless steel model (D), austenite phase (A) and ferrite phase (F).

$\bar{\varepsilon}_{D, a v e .}=\bar{\varepsilon}_{F, a v e .} \cdot V_{F}+\bar{\varepsilon}_{A, \text { ave. }} \cdot V_{A}$

ここに， $\bar{\sigma}_{D, a v e,}, \bar{\sigma}_{F, \text { ave, }}, \bar{\sigma}_{A, \text { ave }}$, はそれぞれ二相材, フェ ライト相, オーステナイト相の相当応力の要素平均,

$\bar{\varepsilon}_{D, a v e,}, \bar{\varepsilon}_{F, a v e,}, \bar{\varepsilon}_{A, \text { ave. }}$ はそれぞれ二相材, フェライト相, オーステナイト相の相当歪みの要素平均である.

これらの関係をオーステナイト体積率 $50 \%$ について 示したのが Fig. 10 である. 点 $D$ はある時点での $\bar{\sigma}_{D, \text { ave. }}$ - $\bar{\varepsilon}_{D, \text { ave. }}$ であり, 点 $\mathrm{F}$ と点 $\mathrm{A}$ はそれぞれそのときの各相

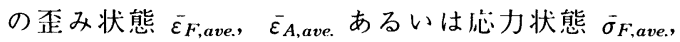

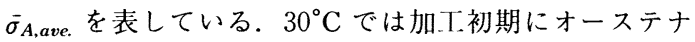
イト相の変形がはやく進行し, 単相の場合よりはやく加 工硬化するため二相材の平均相当心力 $\bar{\sigma}_{D, \text { ave }}$ 。増大し, それはフェライト相とオーステナイト相の平均相当応力 一平均相当歪み曲線との間からはずれて上に位置するよ うになる。

ここで，実験で得られた変形抵抗曲線が，この FEM 計算での平均相当応力-平均相当歪み曲線と同じ傾向を 示すと考えると, 以下のことが言える. Fig. 8 からわか るようにオーステナイト体積率が少ないほどオーステナ イト相の変形がはやいので加工硬化もオーステナイト体

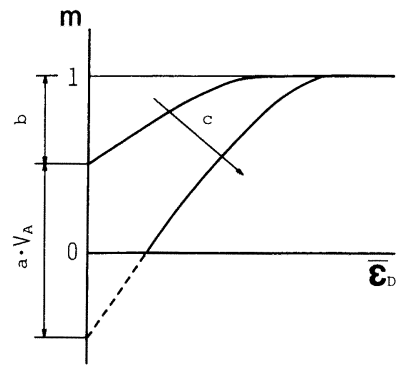

Fig. 11. Schematic illustration of equation (11) for the ratio $m$ of incremental strain of austenite phase to that of ferrite phase.

積率が少ないほど大きい。一方，全体の変形抵抗に寄与 する率は体積率に比例するのでオーステナイト体積率の 小さいほど寄与率が小さい。 よって混命則からの変形抵 抗のずれがいちばん大きいのはオーステナイト体積率が だいたい $50 \%$ のあたりになると考えられる.

一方, $200^{\circ} \mathrm{C}$ ではオーステナイト相がフェライト相よ りはやく変形してもフェライト相とオーステナイト相の 変形抵抗曲線はほほ平行であるため, 二相材の変形抵抗 もこれと平行になる．またこのように両相の変形抵抗 が平行となっている場合は両相の歪みの進行度が違って も，得られる二相材の変形抵抗は両相が均等に変形して 得られる変形抵抗とほほ同じ值になることがわかる。 従って $200^{\circ} \mathrm{C}$ 以上では結果的に混合則が成り立ったも のと考えられる。

\section{5. 二相材の变形抵抗式}

以上の考察をふまえて二相材の変形抵抗式表示を試み る. 二相材の変形抵抗式を次式で表す.

$$
\bar{\sigma}_{D}\left(\bar{\varepsilon}_{D}\right)=\bar{\sigma}_{F}\left(\bar{\varepsilon}_{F}\right) \cdot V_{F}+\bar{\sigma}_{A}\left(\bar{\varepsilon}_{A}\right) \cdot V_{A}
$$

ここに $\bar{\sigma}_{F}\left(\bar{\varepsilon}_{F}\right), \bar{\sigma}_{A}\left(\bar{\varepsilon}_{A}\right)$ はそれぞれフェライト単相材, オーステナイト単相材の变形抵抗曲線である.この $\bar{\varepsilon} F$

と $\bar{\varepsilon}_{A}$ の関係式として，田村らは

$$
\begin{aligned}
& \bar{\varepsilon}_{D}=\bar{\varepsilon}_{F} \cdot V_{F}+\bar{\varepsilon}_{A} \cdot V_{A} \cdot \\
& m,=\bar{\varepsilon}_{F} / \bar{\varepsilon}_{A} \ldots \ldots \ldots . .
\end{aligned}
$$

を用いているが3)，歪みが大きい場合にはその履歴を考 慮する必要があり，大変形の場令この式は適当でないと 考えられる.そこで新たにその時点での二相材の歪み増 分 $d \bar{\varepsilon}_{D}$ と各相の歪み増分の関係

$$
d \bar{\varepsilon}_{D}=d \bar{\varepsilon}_{F} \cdot V_{F}+d \bar{\varepsilon}_{A} \cdot V_{A}
$$

を用いることにし，両相の変形の進行度は式（5）で表 される歪み増分比で考えることにした． $m$ の值は Fig. 9 にみられるように加にの進行とともに変化し，また それは両相の変形抵抗，体積率にも影響される。そこで 
$m$ の式は, 有限要菜法による解析結果の Fig. 9 を参考 にして次のように設定した。

$$
\begin{aligned}
m & =d \vec{\varepsilon}_{F} / d \bar{\varepsilon}_{A}=f\left(\bar{\sigma}_{F}, \overline{\sigma_{A}}, \overline{\varepsilon_{D}}, V_{A}\right) \\
& =1-\left(a \cdot V_{A}+b\right)\left(c \cdot\left(\bar{\sigma}_{F}-\bar{\sigma}_{A}\right) /\left(\bar{\sigma}_{F}+\bar{\sigma}_{A}\right)\right) \bar{\varepsilon}_{D}
\end{aligned}
$$

模式汹を Fig. 11 に表す。 $a \cdot V_{A}+b$ は初期の拘束状態 を表し， $a$ は体積率の影響を表すパラメーターである. 歪み $\bar{\varepsilon}_{D}$ が大きくなると $m$ が 1 に近づくように，すな わち拘束が強くなるようにしてある。 $c$ はその時の1に 近づき方, すなわち拘束度の変化の速さを表すパラメー ターである.また, 両相の変形抵抗が等しくなる時 $\left(\bar{\sigma}_{F}\right.$ 一 $\left.\bar{\sigma}_{A}=0\right)$ にも， $m=1$ となるように設定した。なお， 式の性質上 $m$ がマイナスになるときは $m=0$ とする.

二相材の変形抵抗は式 $(8)$ に各相の歪みを代入するこ とにより決定される。各相の歪みは式(11)，（5)より

$$
\begin{aligned}
& \bar{\varepsilon}_{A}=\int_{0}^{\varepsilon_{1 \prime}} \frac{d \varepsilon_{0}}{V_{A}+m\left(1-V_{A}\right)} \\
& \bar{\varepsilon}_{F}=\int_{0}^{\varepsilon_{1 \prime}} \frac{m \cdot d \varepsilon_{0}}{V_{A}+m\left(1-V_{A}\right)}
\end{aligned}
$$

となる.

ここで,

$$
m=f\left(\bar{\sigma}_{F}, \bar{\sigma}_{A}, \bar{\varepsilon}_{D}, V_{A}\right)
$$

であるが,

$$
\overline{\sigma_{F}}=f\left(\overline{\varepsilon_{F}}\right), \overline{\sigma_{A}}=f\left(\bar{\varepsilon}_{A}\right)
$$

であるので, 結局 $m$ 自身, $\bar{\varepsilon}_{F}$ と $\bar{\varepsilon}_{A}$ の関数 $m=f\left(\bar{\varepsilon}_{F}\right.$, $\left.\bar{\varepsilon}_{A}, \bar{\varepsilon}_{D}, V_{A}\right)$ となる. そのため, $\bar{\varepsilon}_{F}, \bar{\varepsilon}_{A}$ は微小ステップ ごとに逐次数值積分していくことにする.

この方法で本実験で用いた材料について変形抵抗を数 值計算したものを Fig. 4 に示してある. $a, b, c$ の値は $m$ がほぼ Fig. 9 のように推移するような值， $a=1.0$, $b=0.5, c=0.5$ を選んだ.この場合, フェライト単 相材として $\mathrm{F}$ 材は $3 \cdot 2 \cdot 1$ 項で述べたように不適当なの で D1 材と A 材の変形抵抗をもとに, 新たにフェライト 単相材の変形抵抗を計算し，さらにD2, D3, D4 の変

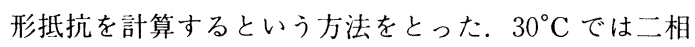
域の変形抵抗は混命則で表される值線より大きくなり, $200^{\circ} \mathrm{C}$ ではほぼ直線になり，実験結果を定性的にうまく 表せたといえる。

\section{6. 結 言}

オーステナイト相, フェライト相の体積率を変えた二 相ステンレス鋼について冷間の範讲で温度を変えて压縮
実験を行い，高歪みまでの変形抵抗を測定した。これよ り次のことがわかった。

(1)二相ステンレス鋼はオーステナイトステンレス鋼の ように䇪温では加厂硬化が大きいが，これは温度の上昇 とともに小さくなる．また，降伏忍力はフェライトステ ンレス鋼のように温度依存が大きい。このように二相ス テンレス鋼はフェライトステンレス鋼とオーステナイト ステンレス鋼の雨方の特徵を持っていることがわかっ た。

また，二相ステンレス鋼をフェライト相とオーステナ イト相からなる二相材としてとらえて考えると次のよう なことがわかった。

(2)二相材の变形抵抗は $200^{\circ} \mathrm{C}$ 以下では混命則に従わ ず，そのずれはオーステナイト体積率 $50 \%$ でもっとも 大きい. $200^{\circ} \mathrm{C}$ では混令則に従った。

(2)の結果について考察を深めるため，有限要素法によ る解析を行った結果次のことがわかった.

(3)加亡初期はオーステナイト相が軟らかいためフェラ イト相より変形量が大きく, 窒温ではオーステナイトの 加厂硬化が大きいため二相材全体の変形抵抗も増加す

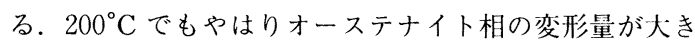
いが, 加工硬化はフェライト相とほぼ同じであり,この ような条件下では混合則に従う結果となった。

これらの考察をふまえて

(4)二相材の構成相の歪み増分の比を表す式を新たに導 入し, 単相材の変形抵抗曲線をもとに二相材の変形抵抗 曲線を計算した。これにより実験結果を定性的にうまく 表すことができた。

\section{文献}

1) 品川一成, 石川孝问, 細井鿆三: 鉄と鋼, 75 (1989), p. 2067

2 ) 曾山義朗: 材料, 15 (1966), p. 17

3 ) 友田 陽, 黑木剛问朗, 田村今男: 鉄と鋼, 61 (1975), p. 107

4 ) 友田 陽, 田村今男: 鉄と鋼, 67 (1981), p. 439

5 ) 友田 陽, 田村今男: 鉄と銅, 68 (1982), p. 1147

6 ) $N$. C. Goel, S. SAngal and $K$. Tangri: Metall. Trans. A, 16 (1985), p. 2013

7 ) S. ANKEM and H. MARGolin: Metall. Trans. A, 17 (1986), p. 2209

8 ) P. D. Funkenbusch, J. K. LeE and T. H. Courtney: Metall. Trans. A, 18 (1987), p. 1248

9 ) $K$. Osakada, $T$. KawaSaKi and $K$. Mori: Ann. CIRP, 30 (1981), p. 135

10) $K$. Mori, $K$. Osakada and M. Fukuda: Int. J. Mech. Sci., 25 (1983), p. 775 